\title{
What can be the Role of Public-Private Partnerships and the role of the Collective Action in Ensuring Sustainable Smallholder Participation in High Value Fruit and Vegetable Supply Chains in Albania?
}

\author{
Prof. Asc. Dudi SULI ${ }^{1}$; MSc. Florjan BOMBAJ ${ }^{2}$, MSc. Hergys SULI ${ }^{3}$ \\ MSc. Gjergj XHABIJA ${ }^{2}$
}

\begin{abstract}
:
Albania is a Mediterranean country where fruits and vegetables occupy an important place in the cropping systems practiced by the Albanian farms but also in the food consumption of the population. Today, the fruits and vegetables growers in Albania have low production capacity and difficulties in selling their products on national and regional market. These poor producers face problems of how to produce safe food (World Bank 2007), be recognized as producing safe food, identify cost-effective technologies for reducing risk, and be competitive with larger producers with advantage of economies of scale in compliance with food safety requirements. In enabling the smallholders to remain competitive in such a system, new institutional arrangements are required. The new and emerging food system (dominated by domestic urban market and export markets, regional competitiveness, globalization, etc.) with high demands for compliance with food safety and traceability disfavor the smallholders due to high coordination costs. The problem is exacerbated by geographic dispersion, low education, and poor access to capital and information (Poulton 2005; Humphrey 2005; Rich and Narrod 2005). The main idea of this paper is that the public-private partnerships can play a key role in creating farm to fork linkages that can satisfy the market demands for food safety while retaining smallholders in the supply chain. Our big question is "how this can be possible in Albania and which are the right policies to forward this idea?"
\end{abstract}

Keywords: Sustainable Development; Added Value; Collective Action.

\section{The Neo-Institutional Economics Framework}

The new and emerging food system (dominated by domestic urban market and export markets) with high demands for compliance with food safety

${ }^{1}$ Department of Agricultural Political Economy, ${ }^{2}$ Departament of Finance and Accounting, Agricultural University of Tirana, Albania

${ }^{3}$ Plus Communication, Tirana, Albania 
and traceability disfavor the smallholders due to high coordination costs. The problem is exacerbated by geographic dispersion, low education, and poor access to capital and information (Poulton 2005; Humphrey 2005; Rich and Narrod 2005). The smallholders face problem in the two dynamic markets in meeting the standards as well as in ensuring the delivery of a regular supply to their buyers. The list of constraints that smallholders face in the HVA markets given below draws from Rich and Narrod (2005):

- High fixed costs in production and marketing, especially due to the need to comply with the standards given high perishability (Sykuta M and Cook M, 2001; Codron JM, 2008).).

* Difficulties in guaranteeing safe products. This can arise either in terms of the quality or the misuse of inputs or the lack of knowledge about the introduction, growth, and transport of pathogens, which can be magnified as products move along the supply chain. For credence goods, reputation matters significantly for demand creation. Smallholders usually have a small history of presence in the markets and lack branding (Tallec, 2004).

* Asymmetric and incomplete information and high transaction costs may exist between actors in the supply chain. Lack of information regarding production and marketing can especially deter smallholders as procurement and processing of information involves large fixed costs (Barzel, 1982).

* Lack of incentives and resources to invest in quality improvement, low access to credit, and the low returns from investing in quality (as they lack reputation) disadvantage the small farmers (Markelova \& al, 2009).

In HVA chains, smallholders are thus likely to face problems in quality control, handling, and storage (Bienabe and Sautier 2005). Moreover, once involved in HVA chains, smallholders individually enjoy only limited bargaining power.

\section{Role of Institutions in enabling smallholder's market access in HVA chains}

Conceptually, the role of Collective Action arises wherever there are economies of scale in production or in marketing. This includes the role of farmer groups in being better able to ensure traceability. In these chains, the costs for the establishment of traceability are lower for firms and farms with collective action than without it. Similarly, collective action has a rationale if agents in the supply chain have different comparative advantages. Thus, a producer group (with comparative advantage in production) could benefit from collaboration with agents that have expertise in marketing. 
The table below presents a summary of the different processes and the role that CA plays in each context. This list is not intended to be exhaustive but is aimed at presenting indicative cases pointing to a basis for CA. In exporting, information about the demands of the markets and the terms and conditions of the contract and the process of the establishment of contracts has to precede the production process. Procurement and processing of information clearly involves fixed costs.

Table 1. Production processes in markets with IFSS ${ }^{1}$ and the role of collective action

\begin{tabular}{|c|c|}
\hline Supply Chain Process & Role played by collective action \\
\hline Pre- production & $\begin{array}{l}\text { Procurement of information about markets and the process of } \\
\text { formation of contracts } \\
\text { Dissemination of the information relating to IFSS } \\
\text { Undertaking of lumpy investments }\end{array}$ \\
\hline Production & $\begin{array}{l}\text { Procurement of cheaper inputs through bulk buying } \\
\text { Use of extension services } \\
\text { Establishment of traceability system }\end{array}$ \\
\hline $\begin{array}{l}\text { Post harvest and } \\
\text { Marketing }\end{array}$ & $\begin{array}{l}\text { Collective marketing leading to reduced costs (for example in } \\
\text { transport) Grading and certification for the farmer groups } \\
\quad \text { Collaboration with marketing experts }\end{array}$ \\
\hline
\end{tabular}

Source: Rich and Narrod (2005)

The traditional public supply functions can be inadequate to meet the needs of the HVA supply chains from the perspective of the smallholders. Traditional public sector activities such as extension, research and development, and price and marketing policies have been largely commodity-based and hence may not provide the support smallholders require in a HVA supply chain. The private sector has traditionally been directly involved in the production, marketing, and distribution of agricultural commodities, the rise in HVA commodities giving an ever-larger and more specific role to the private actors. Table 3 presents the different supply chain support processes and the institutional roles played by the private and the public sectors. Wherever the public or the private sector by itself cannot provide the supply chain support that caters to the needs of the smallholders, there arises a need for partnerships.

\footnotetext{
${ }^{1}$ International Food Safety Standards
} 
Table 2. Public and Private sector roles in the supply chain management of HVA

\begin{tabular}{|c|c|c|c|c|}
\hline $\begin{array}{l}\text { Supply Chain } \\
\text { Support Processes }\end{array}$ & $\begin{array}{lll}\text { Needed } & \text { Roles } & \text { for } \\
\text { SCM } & & \end{array}$ & Public Sector & Private Sector & $\begin{array}{lr}\text { Market } & \text { or } \\
\text { government } & \text { failures } \\
\text { affecting } & \\
\text { smallholders } & \end{array}$ \\
\hline Extension services & $\begin{array}{l}\text { Knowledge of } \\
\text { specialized } \\
\text { techniques for } \mathrm{HVA}\end{array}$ & $\begin{array}{l}\text { Technical assistance } \\
\text { in farming practices }\end{array}$ & $\begin{array}{l}\text { Services to farmers } \\
\text { and firms linked to } \\
\text { private company }\end{array}$ & $\begin{array}{l}\text { Low and variable } \\
\text { access to public or } \\
\text { private extension; } \\
\text { limited } \\
\text { knowledge of new } \\
\text { techniques }\end{array}$ \\
\hline $\begin{array}{l}\text { Infrastructure } \\
\text { development }\end{array}$ & $\begin{array}{l}\text { Management of } \\
\text { flows between chain } \\
\text { links quickly and } \\
\text { efficiently; Reduce } \\
\text { distribution costs to } \\
\text { remain competitive }\end{array}$ & $\begin{array}{l}\text { Public infrastructure } \\
\text { (roads, ports, storage } \\
\text { facilities); public } \\
\text { distribution }\end{array}$ & $\begin{array}{l}\text { Private infrastructure } \\
\text { (processing, storage); } \\
\text { logistics }\end{array}$ & $\begin{array}{l}\text { Uneven development } \\
\text { biased against } \\
\text { smallholders, private } \\
\text { development difficult } \\
\text { for smallholders or } \\
\text { not attuned to small } \\
\text { farmer's needs }\end{array}$ \\
\hline $\begin{array}{l}\text { Information } \\
\text { services }\end{array}$ & $\begin{array}{l}\text { Integration of } \\
\text { information flows } \\
\text { across supply chain }\end{array}$ & $\begin{array}{l}\text { Provision of public } \\
\text { statistics on prices, } \\
\text { production, } \\
\text { information } \\
\text { varieties on } \\
\text { extension }\end{array}$ & $\begin{array}{l}\text { Private marketing } \\
\text { information services } \\
\text { (MIS) and electronic } \\
\text { data interchange } \\
\text { (EDI) }\end{array}$ & $\begin{array}{l}\text { Reliance on public } \\
\text { information systems } \\
\text { not tuned to market } \\
\text { needs, exclusion } \\
\text { from private sources } \\
\text { for inability to pay }\end{array}$ \\
\hline $\begin{array}{l}\text { Certification, } \\
\text { grades, } \\
\text { standards }\end{array}$ & $\begin{array}{l}\text { Consistent, credible } \\
\text { application of } \\
\text { standards on food } \\
\text { safety and quality } \\
\text { specifications }\end{array}$ & $\begin{array}{l}\text { Public certification } \\
\text { and development } \\
\text { and enforcement of } \\
\text { public standards and } \\
\text { regulations }\end{array}$ & $\begin{array}{l}\text { Private certification } \\
\text { and development } \\
\text { and enforcement of } \\
\text { private standards; }\end{array}$ & $\begin{array}{l}\text { Smallholders }{ }^{6} \text { ability } \\
\text { to meet public or } \\
\text { private standards } \\
\text { limited; } \\
\text { Development not } \\
\text { based on smallholder } \\
\text { needs }\end{array}$ \\
\hline $\begin{array}{l}\text { Coordination } \\
\text { mechanisms }\end{array}$ & $\begin{array}{l}\text { Ensuring consistent } \\
\text { delivery of high- } \\
\text { quality products }\end{array}$ & $\begin{array}{l}\text { Creation and } \\
\text { enforcement of } \\
\text { regulations to ensure } \\
\text { competition; } \\
\text { mandatory } \\
\text { cooperatives } \\
\text { (centrally-planned } \\
\text { economies) }\end{array}$ & $\begin{array}{lr}\text { Development } & \text { of } \\
\text { contracts } & \text { and } \\
\text { marketing } & \\
\text { agreements } & \text { with } \\
\text { suppliers } & \end{array}$ & $\begin{array}{l}\text { Limited enforcement } \\
\text { of contracts biased } \\
\text { against small farmers; } \\
\text { divergence in market } \\
\text { power between chain } \\
\text { actors }\end{array}$ \\
\hline
\end{tabular}

Source: Rich and Narrod (2005)

\section{Introduction to Albanian reality}

Since it began the transition to a market economy in 1991, Albania's economy has made impressive progress, with incomes recovering to pre-transition levels. However, the agriculture sector has fallen behind, with productivity lagging significantly behind the agricultural sectors of Albania's neighbors and the rest of Europe. A substantial portion of agricultural production takes place just to 
provide income support to the rural poor. Productivity has improved in recent years, possibly as a function of capital accumulation, and the sector appears to have potential for growth. But important constraints to competitiveness need to be overcome to increase Albania's competitive advantage in agricultural production, against a backdrop of increasing regional competition and the eventual need to harmonize with EU legislation and standards.

\section{An overview for the vegetable supply chain}

\section{a) Some data analysis and problems of the vegetable supply chain}

Up to 1990, Albania's total vegetable production was approximately 400.000 tons, originating from 18000 ha open field production and 1100 ha of greenhouses. This production was undertaken mainly by State owned enterprises and cooperatives and the average yield was around 22.22 MT per Ha. The table 1 the average export volumes between 1980 and 1990:

\section{b) High cost of production at farm level}

A number of reasons impact on farm input costs: Farms remain relatively small (average size is $1.3 \mathrm{Ha}$ for professional farms) due to problems with obtaining legal title for land.Today, the total vegetable production is around 600.000, originating from 35000 ha open field production and $45000 \mathrm{~T}$ from 660 ha of greenhouses. Average yields are 22, 43 tons per Ha (MAAPC 2007). This decrease in productivity can be explained by three factors: (a) limited access to modern production technologies; (b) the break-up of cooperative structures that facilitated product transfer (Meço M, Musabelliu B, 2003); (c) Difficulties with field irrigation. Some farms do not have any water advantage whilst others have been forced to dig wells to obtain the necessary supplies. In addition, some farmers have been forced to install drip irrigation systems that are with low quality and not fully complete (they have short life and miss the filtering systems against alga and other organisms one and/or multi cells that block the drippers). Some other farmers have got drip lines which are not of pressure self-regulation type (so the water quantity reaches the drippers is different along the drip-line). Based on this situation, export potential still remains substantial and can be forecast in the table 1 below. Although $85 \%$ of land is formally registered, land owner compensation procedures have still not been fully resolved. Input costs like seeds, sprays and fertilizers are rather high. This is also an outcome of small farm size reducing bargaining power. Lack of access to finance leads to difficulties not only in adopting new technology, but forces farmers to undertake a wide range of tasks such as production and marketing. Unfortunately, many 
farmers are not skilled in any of the non-production related disciplines and their effectiveness is thus reduced. Thus, productivity is low and the cost of production is high. For instance, the average yield is approximately 22.29 tons of vegetables.

Table 3. Average export volumes between 1980 and 1990

Items for Export

Tomatoes

Cucumbers

Watermelon

Paprika

Carrot

Leek

Beans

Potato
Quantity in tons 5000-6000 500-1000 10000-15000

$1000-1500$

500-1000

1000-1500

$500-600$

$100-1500$
Table 4. Export potential for the vegetable sector

Items for Export

Tomatoes

Cucumbers

Water Melon

Paprika

Leek

Carrot
Quantity in tons

$32000-35000$

$3000-4000$

$15000-16000$

2000-2500

$3000-3500$

2000-3000

Source: UNDP (2005)

\section{c) Lack of well established wholesalers and related infrastructures}

The linkage between producers and consumers is at best very weak and in most cases totally absent. Generally, traders appear around harvesting time and operate in a non-contractual, unstructured manner - both with producers and foreign markets. They certainly lack transportation capacity and need a more robust logistics infrastructure. When coupled with variation in quality, export becomes very difficult (World Bank 2007).

\section{d) Insufficient market information}

The lack of market information about both the domestic and export market prevents traders from finding niche markets and from signing contracts. Not only have these hampered effective and beneficial sales negotiations by reducing knowledge of prices and sales locations, it also restricts their ability to plan crop types and planting schedules (World Bank 2007). 


\section{Trade Relations Vegetable Value Chain}

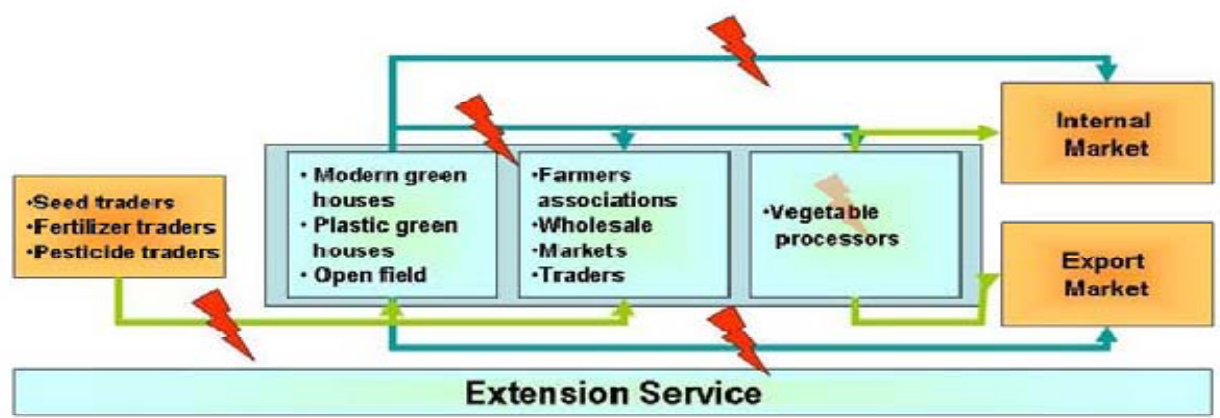

Scheme 1. Trade relations vegetable value chain

2. An overview for the fruits supply chain (olive trees as the most important fruit of this supply chain)

There are between 3.6 up to 4.1 million olive trees in Albania. They are distributed as follow:

$\begin{array}{lr}\text { Table 5. Potential of fruits production in Albania } \\ \text { Vlore } & 15 \% \\ \text { Berat and Kuçova } & 13 \% \\ \text { Saranda and Delvina } & 11 \% \\ \text { Tirana } & 8 \% \\ \text { Mallakastra } & 6 \% \\ \text { Lushnje } & 6 \% \\ \text { Others } & 41 \%\end{array}$

Source: UNDP (2005)

The mix of quality of olive oil is as follow: (i) extra virgin $-5 \%$, (ii) virgin $-30 \%$, (iii) ordinary virgin $-40 \%$ and (iv) lampante $-25 \%$. The growth potential is around 24 million olive trees.

Some problem areas:

a) Primary Production

The biggest problem in olive oil value chain seems not to be in the processing level (though there are problems at this level as well) but at primary production level: treatment of diseases, cutting, feeding, harvesting, post-harvesting practices, etc. Bottlenecks are: primary production (services and post harvesting 
practices) level, processing (storing) and marketing (bottling and labeling) level. Therefore the quality of the fruit is very low.

\section{b) Poor quality of fruits}

Apart from the importance of investment in planting new olive trees, also the existing olive tree plantations are subject to serious neglect. Even minimal services such protection against insects, pest and diseases, cutting, fertilization; labouring, etc. are not being carried out. This results in low fruit quality and insufficient supply to the processing industry (World Bank 2007).

\section{c) Lack in Cooperation}

The problems mentioned in 1 could be dealt with helping farmers to organize associations or cooperatives. Whilst cooperation is very difficult in Albania, it is possible in selected areas. The cooperative helps to consolidate the supply and exploit the capacity of the olive oil plants, which is underemployed now due to interrupted supply (World Bank 2007).

d) Relationship olive producers \& olive growers:

Relations between the olive growers and olive producers are very poor because they do not understand the mutual benefits of working closely together in order to improve the supply chain to factories with olive quantities that do not cause oversupply and accumulation of raw material for certain time (which cause the decline of the quality of the oil produced)

\section{Trade Relations Olive Value Chain}

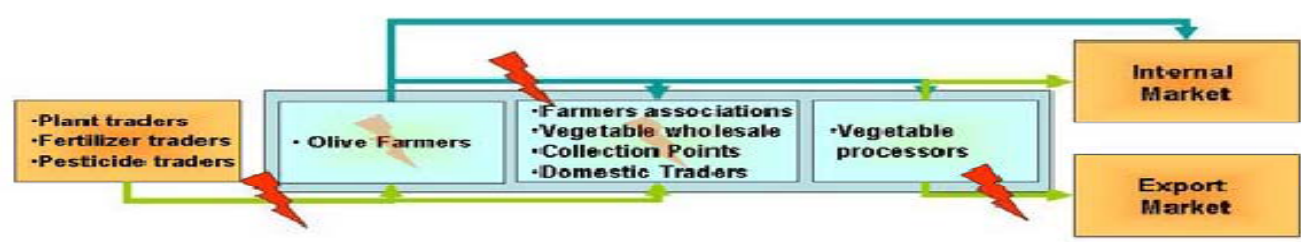

Extension Service

Scheme 2. Trade relations Olive value chain 


\section{Conclusions and recommendations}

The most important findings from our empirical survey are:

1. Access to customer seems to be the biggest problem for farmer

2. Standard compliance is already understood as important issue. Still the access to facilities is not Sufficient

3. Input producers are too small for using economies of scale

4. Grading packaging and labeling is considered as a main constraint

5. Farmers needs collection points where they have access to packaging, grading and

labeling facilities

a) Solutions ideas for the vegetable supply chain:

Establish well equipped produce collection points for packaging, grading, labeling and testing
$>$
Establish wholesale market for locate storage capacities
Design and implement an export platform for supporting private companies and associations

$\begin{array}{ll}> & \text { Support cooperatives to collect and market vegetable produce } \\ \text { export promotion agency. } & \text { Support-legal, business plans, etc, framers group }\end{array}$

b) Solutions ideas for the olive trees supply chain:

Increasing the number of olive trees and Administration of olive trees as a national priority patrimony

Consolidation of olive tree ownership through promoting market transactions and taxation policy

falsification

Better enforcement of olive oil law to fight against olive oil

Supporting farmers cooperatives/associations through injection of outside financial support based on farmers' needs

Facilitation of farmers' brainstorming to identify their concrete needs that would promote cooperation

Adoption of HACCP and ISO standards. Today export is being done on a ad hoc basis

Support establishment of olive farmers' associations 


\section{References}

Barzel Y, 1982. Measurement Costs and the organization of Markets. Journal of Law and Economics 25(1), p. 27-48.

Bienabe, E. and D. Sautier. 2005. The role of small scale producer's organizations to address market access, Paper presented at the International Seminar Beyond Agriculture: Making Markets Work for the Poor, London, UK, 28 Feb.-1 Mar.

Codron, J.M., Sterns, J.A., et Reardon, T. 2000. «Consumer preferences, experience and credence issues and their strategic implications for French and US Fresh Produce sectors», a contributed paper for presentation at the 2000 international food and agribusiness management forum, June 24-25, 2000, Chicago, 19 p.

Granovetter, M., 1985. "Economic action and social structure: The problem of embeddedness », American Journal of Sociology, vol. 91, p. 481-510.

Humphrey, J. 2005. Shaping value chains for development: Global value chains in agribusiness, Paper written for the Deutsche Gesellschaft fur Technische Zusammenarbeit (GTZ).

Markelova et al, 2009. Collective action for smallholder market acces. Food policy vol. 34, p 1-7. Meço M, Musabelliu B, 2003. "Kooperativat e Fermereve dhe Organizimi i tyre".

Poulton C. 2005. Presentation made at the The future of small farms. Research Workshop (IFPRI, ODI and Imperial College)-June, 26-29, 2005 Withersdane Conference Centre, Wye, UK

Raynaud E., Sauvée L., Valceschini E., 2009. Aligning Branding Strategies and Governance of Vertical Transactions in Agri-food Chains, Industrial and Corporate Change 18, 1-34.

Rich, K.M. and C. A. Narrod. 2005. Perspectives on supply chain management of high value agriculture: The role of public-private partnerships in promoting smallholder access. Draft.

Sylvander, B., 1995. «Conventions de qualité, marchés et institutions : le cas des produits de qualité spécifique». In F. Nicolas et E. Valceschini (eds.), Agro-alimentaire : une économie de la qualité. INRA Editions, Economica, pp. 167-185.

Tallec, F., 2004. «Rôle de l'action collective dans la construction de la qualité dans une filière agroalimentaire, analyse des différentes formes de coordination des commerçants de la filière des céréales sèches au Mali». Thèse de doctorat, sous la dir. de D. Requier-Desjardins, Université de Versailles-Saint-Quentin-enYvelines, $326 \mathrm{p}$.

Thorp et al, 2007. Group Inequalities and the Nature and Power of Collective Action. World Development, Vol. 35, n. 11, p. 1929-1946

UNDP (United Nations Development Programme), 2005. Marketing and Distribution Chain Study

Williamson, Oliver. 1975. Markets and Hierarchies: Analysis and Antitrust Implications. Free Press: New York.

World Bank, 2007. Albania Strategic Policies for a More Competitive Agriculture Sector, $162 \mathrm{p}$. 